\title{
Public Expenditure Management in Francophone Africa: A Cross-Country \\ Analysis
}

Yaya Moussa 


\title{
IMF Working Paper
}

Fiscal Affairs Department

Public Expenditure Management in Francophone Africa: A Cross-Country Analysis

Prepared by Yaya Moussa ${ }^{1}$

Authorized for distribution by Ehtisham Ahmad

March 2004

\begin{abstract}
This Working Paper should not be reported as representing the views of the IMF.

The views expressed in this Working Paper are those of the author(s) and do not necessarily represent those of the IMF or IMF policy. Working Papers describe research in progress by the author(s) and are published to elicit comments and to further debate.
\end{abstract}

There are strong similarities between the French and French-inspired African PEM systems in terms of the legal setting, rules, and procedures. However, there are differences in practice, particularly in accounting and reporting, audit, and external control. Among the African countries themselves, there are many common features but also marked differences in audit and external control.

JEL Classification Numbers: H50, H61

Keywords: Budgeting, Public Expenditure Management, Technical Assistance, Africa Author's E-Mail Address: ymoussa@imf.org

\footnotetext{
${ }^{1}$ The author is a staff member in the Fiscal Affairs Department (FAD) of the IMF. He would like to thank Ehtisham Ahmad and Eivind Tandberg for suggestions; Dominique Bouley (FAD) and Iraj Talai (World Bank) for their help in reviewing the PEM questionnaire; and colleagues of FAD's PEM divisions and the IMF's African Department for their useful comments. The author is also grateful to Mrs. Robertson, Mrs. Portaro, and Mrs. Fetzer for editorial assistance.
} 
Contents

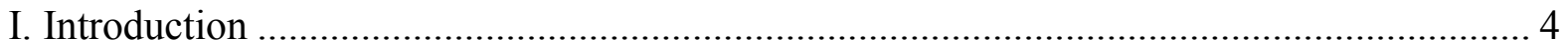

II. Key Public Expenditure Management (PEM) Features of French Reference Model .......... 5

A. Institutional and Legal Context of Budgeting in France: An Overview ........................ 5

B. Normal Expenditure Process: Engagement/Liquidation/Ordonnancement/Paiement

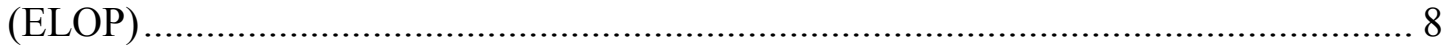

C. Strict Segregation of Duties Between Credit Managers and Accountants..................... 9

D. Control of Budget Execution .............................................................................. 10

E. Some Questions About the Traditional French PEM System .................................. 11

III. Comparing French and African PEM Systems ....................................................... 12

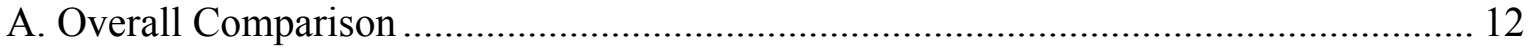

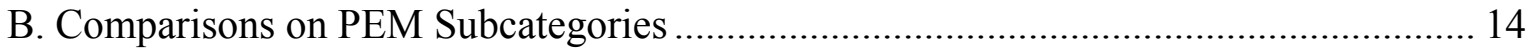

C. Most Divergent Individual PEM Questions ........................................................ 20

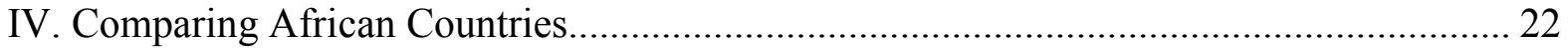

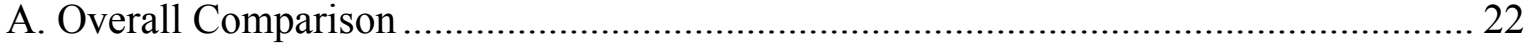

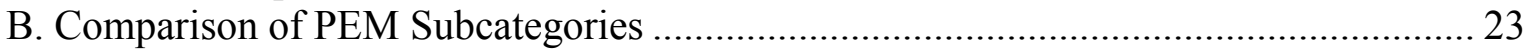

V. Technical Assistance (TA) Policy Implications and Conclusions ................................ 25

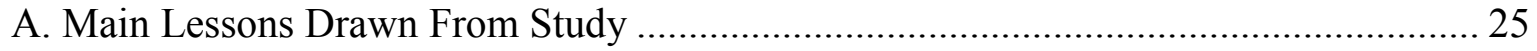

B. Challenges and Policy Decisions for African Countries ......................................... 25

C. Challenges and Policy Decisions for TA Providers ............................................... 27

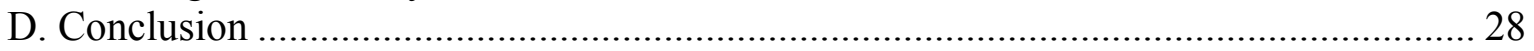

Appendixes

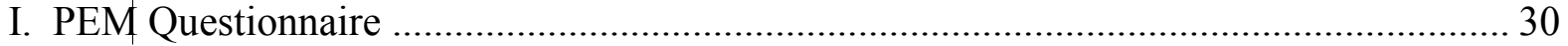

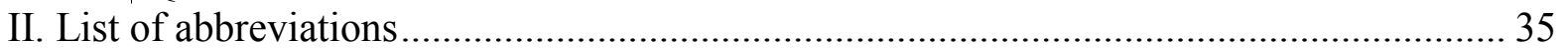

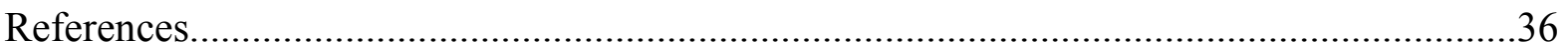

Boxes

1. Complementary Period............................................................................................. 7

2. Measurement of Domestic Government Arrears.........................................................

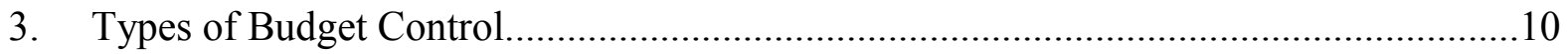

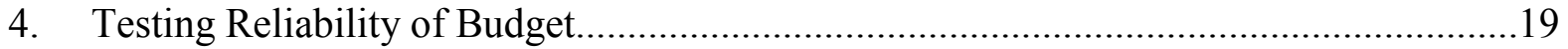

Tables

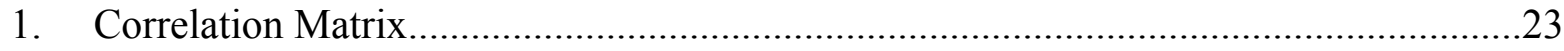

2. Dispersion Among African Countries in PEM Subcategories......................................24 


\section{Figures}

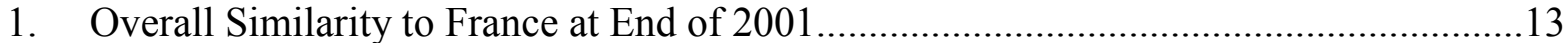

2. Similarity to France at End of 2001 by PEM Subcategories.......................................17

3. Similarity Index by Individual Questions.........................................................21 


\section{INTRODUCTION}

This paper undertakes a cross-country study ${ }^{2}$ to compare francophone African public expenditure management (PEM) systems by addressing numerous concerns, from both analytical and policymaking standpoints. It analyzes similarities in the francophone African PEM systems and whether there are divergences both between them and the French system and among the francophone African countries themselves. The paper also indicates which PEM areas could constitute priorities for technical assistance (TA).

The paper does not attempt to provide a performance rating of francophone African countries or to define performance benchmarks against which PEM systems should be systematically assessed. It only compares PEM systems, highlights similarities and differences among them, and draws some lessons for TA implementation. Francophone African countries both borrowed a lot (in terms of institutional design of PEM systems) and departed considerably from (in terms of the daily practice of PEM) the original French PEM system. A question is whether there is a francophone PEM model or, whether, in light of similarities and differences among countries, it is inappropriate to talk of such a model.

The questionnaire constructed for the study comprises 55 items, 49 specific questions relating to the "nitty gritty" of expenditure management, and six questions pertaining to general information on countries. The questionnaire is Appendix I.

The 49 specific questions on the PEM systems have been grouped into the following six subcategories: 10 questions on legal and institutional environment; five questions on fiscal rules; 14 questions on expenditure process and internal control; seven questions on accounting and reporting systems; two questions on cash plan; and 11 questions on audit and external control.

The analysis in this paper is based on the responses of senior officials from a range of countries at the end of 2001. The 12 African countries surveyed were Benin, Burkina Faso, Cameroon, Chad, the Republic of Congo, Côte d'Ivoire, Guinea, Madagascar, Mali, Niger, Senegal, and Togo. Questionnaires were sent to the ministries of finance and IMF resident fiscal advisors where applicable. Data sent back by respondents were reviewed by IMF experts at headquarters. As usual, responses to questionnaires are subject to uncertainties and bias.

In this paper, Section II underlines the key features of the French PEM system, which serves as a reference for French-speaking African countries. Reference here means a historical reference, not a prescribed model. Section III compares the PEM systems in a sample of francophone African countries with the reference model. Section IV compares African PEM

\footnotetext{
${ }^{2}$ The IMF, the World Bank, and the African Development Bank jointly organized a seminar in Dakar, Senegal in February 2001. As a follow-up to the Dakar seminar, another gathering took place in Abidjan, Côte d'Ivoire in June 2002, with more country cases presented. At the latter, country officials also were involved in both the presentation of cases and the ensuing debates. The preliminary conclusions of the present study were presented in Abidjan.
} 
systems among themselves; and Section V examines challenges and draws some policy lessons for both African countries and their TA providers. Appendix II provides a list of abbreviations used in this paper.

\section{Key Public Expenditure Management Features of the French Reference MODEL}

\section{A. Institutional and Legal Context of Budgeting in France: An Overview}

\section{The 1959 Ordinance (Organic Budget Law) and Decree of 1962 on Public Accounting}

These two major texts shaped the legal framework of budgeting in France until 2001. Three types of budget laws are passed by Parliament: (1) the initial budget law, which includes all annual government revenues and expenditures; (2) the supplementary budget law, which modifies the initial budget during its execution; and (3) the budget review law, which reconciles the executed budget with the initial budget, following the closing of the fiscal year. The review law establishes that Parliament has the first (voting on the initial budget law) and also the last word (voting on the review law) with regard to the use of public money.

In normal circumstances, the approval of the budget by Parliament is a prerequisite for the executive branch to use public money. The vote authorizes the executive branch to spend, through appropriations of credits, as stipulated in the 1958 Constitution. ${ }^{3}$ In principle, the initial budget law both defines the broad categories for the use of credits, and caps the amount of those credits. According to their use and amount, there are three broad categories of appropriations:

(1) Capped appropriations (crédits limitatifs): as a general rule, spending commitments and orders to pay are capped by the budget law. The next two types of appropriations are the exceptions.

(2) Provisional appropriations (crédits provisionnels): the amounts of such appropriations are tentative. If need be, the government can supplement these appropriations from other sources (i.e., from charges communes or general fund accounts, and through decrets d'avance or supplementary credit approval). The typical case is the spending necessitated by natural disasters.

\footnotetext{
${ }^{3}$ However, two main exceptions have been introduced by the 1958 Constitution. The government may issue decrees to ensure the continuity of public service (services votés), if the draft budget law is not presented in time, and if the Parliament does not pass the draft budget law in time, the executive branch can resort to ordinnances, or special payments.
} 
(3) Estimated appropriations (crédits évaluatifs): their amounts are also tentative. The budget figures are only estimates, and they can be increased. Typical examples include debt repayments and litigation costs.

Budgeting is embedded in four key principles: unity, annuality, universality, and specialty. Unity means that the budget should contain all government revenues and expenditures, and that those revenues and expenditures should be contained in a single document. The customary division of the central government budget into three components - namely, the general budget, the ancillary budgets (budgets annexes), and the Treasury special accounts (comptes spéciaux du Trésor) - is not a breach of the principle of unity. Indeed, those three parts better detail the content of the budget and constitute the budget law. Annuality refers to the fact that the budget is approved and executed on an annual basis. Universality means that all government revenues and expenditures are incorporated in the budget and that revenues finance expenditures, without any specific allocation of certain revenues to certain expenditures (earmarking); the principle of universality also precludes the netting of revenues (revenue minus expenditure, hence reporting only the balance). Specialty of spending allows Parliament to authorize the executive branch to spend not the overall budget, but specified categories of credits; in effect, the budget is categorized by ministry, and then the spending ministries apportion the credits within their own sub-administrations.

Different actors are involved in budget preparation, budget execution, and budget control. The segregation of duties among the executive, the legislative, and the judiciary branches of government is laid down in the Constitution. The executive branch, notably the minister of finance, under the supervision of the prime minister, prepares the draft budget law after consultations with the spending ministries. Once the draft is approved and voted by Parliament, it becomes the annual budget law. The budget is executed by the executive branch. Once the credits have been authorized, the spending process has four main phases: engagement, liquidation, ordonnancement, and paiement. The ex post control of the budget is performed by Parliament and by the Public Audit Office (Cour des Comptes).

\section{Budget calendar and treasury cycle}

The budget calendar (the fiscal year runs from January 1 to December 31 ) defines specific deadlines to be met with regard to the administrative and accounting phases of the spending process. An important issue is which fiscal year each expenditure should pertain to. ${ }^{4}$ Different deadlines limit the two types of expenditures. For spending requiring an order to pay, such as salaries and capital spending, the origination act (engagement) can take place between January 1 and December 31. For current expenditures other than salaries, November 30 is the deadline (postponed to December 31 in the case of emergency); December 31 is the last day for giving the order to pay and the actual payment should take place before January 15 of the next year. Adjustment operations (e.g., a change in accounting imputation or

\footnotetext{
${ }^{4}$ This discussion raises the general point as to whether a financial transaction relates to the year in which it actually occurs (système de gestion) or to the budget year in which the appropriation was noted (exercice).
} 
clearing of suspense accounts) could be conducted until January 15 for the principal accountants, February 12 for the accountants designated by the finance ministry, and until February 23 by the Agent Comptable Central du Trésor (ACCT), which is in charge of accounts consolidation. For spending not requiring an order to pay, the spending is accounted for during the year of actual payment. The complementary period is the period that stretches beyond fiscal year $n$, but which is linked to that fiscal year. Over time, France has shortened the complementary period; it is now limited to one month.

\section{Box 1. Complementary Period}

\section{Definition}

Transactions relating to fiscal year $n$ can span up to three fiscal years $(n-1, n$, and $n+1)$. Indeed, some of fiscal year $n$ spending may be made ahead of time in $n-1$, as anticipated payments, and other payments can occur belatedly in early $n+1$. The complementary period is the short period (officially 30 to 60 days, depending on countries) that stretches beyond fiscal year $n$, but whose transactions are linked to fiscal year $n$.

\section{Two types of complementary periods}

Normally, the additional time allowed to close budget execution serves to regularize budget operations which were pending at the end of the fiscal year. This regularization can for instance consist in clearing residual payment orders (in the case of the administrative complementary period) or making proper itemization of spending (in the case of the accounting complementary period).

In reality, a long complementary period may be the result of lax budget spending procedures (i.e., unobserved closing dates of commitments and orders to pay or a fluctuating budget calendar). ${ }^{1}$

\section{Reporting issues relating to the complementary period}

Fiscal reporting can cover the transactions pertaining to a specific fiscal year as defined by the budget (legal approach) or, in and out financial flows occurring in a specific year (cash approach).

Budgetary transactions are linked to the fiscal year during which they are supposed to occur. As a result, if the transaction dates are overstretched beyond the fiscal year, then the difficulty of linking them to their original fiscal year is evident.

\footnotetext{
${ }^{1}$ According to the West African Economic and Monetary Union (WAEMU), the complementary period should be limited to two months. In other words, if December 31st is the end of the fiscal year $n$, then transactions pertaining to $n$ but which have actually occurred by end-February $(n+1)$ should be linked to fiscal year $n$.
}

\section{Treasury Single Account}

This central principle of a treasury single account (TSA) entails that the government (via the Treasury) concentrates its cash resources in one account, usually held in the central bank. But many other institutional arrangements underpin the French concept of the TSA. Indeed, the 1959 Ordinance stipulates that local governments and public agencies, also known as Treasury correspondents, shall deposit all their funds at the Treasury, hence it is a pool of cash emanating from different public entities. The pooling of public funds has the unity of cash desk (unicité de caisse) as a corollary: a public accountant is just one cashier, even 
though he serves many public entities. ${ }^{5}$ The financial links between the Treasury and the correspondents is called the "Treasury circuit." It helps to manage public funds better by showing the status of consolidated government cash at any given time and allowing the transfer of cash from entities having a cash excess to those experiencing a cash shortage.

\section{New Organic Budget Law and changes to come}

The August 1, 2001 Financial "Constitution" of France is ambitious but coherent: it aims to modernize not only the budgeting framework specifically, but also the public management system in general. The main innovations include the introduction of a result-oriented budget, accrual accounting, an annual certification by the Public Audit Office (Cour des Comptes), and an increase of legislative control. The new law stipulates a progressive implementation period, from 2002 to $2006 .{ }^{6}$ In the meantime, the 1959 Ordinance and the Decree of 1962 continue to constitute the backbone of the legal framework of budgeting.

\section{B. Normal Expenditure Process: Engagement/Liquidation/Ordonnancement/Paiement $(\text { ELOP })^{7}$}

Once budget appropriations are allocated to spending ministries and agencies, the spending circuit starts with "engagement" (origination of the spending). The second phase is "Iiquidation" (validation of the expenditure). The good or service ordered has been delivered and the amount of government debt is calculated; the government debt then becomes actual and its repayment is legally due. The next phase is "ordonnancement" (order to pay). A credit manager gives the order to pay the government debt resulting from the previous spending phases to a public accountant. At the last phase, which is "paiement," a public accountant disburses money to honor the government's commitment.

\footnotetext{
${ }^{5}$ The principle of the unity of the cash desk was instituted in 1806.

${ }^{6}$ Several observers believe that the full implementation of the 2001 organic budget law will take longer than anticipated in the legislation.

${ }^{7}$ Origination/validation/order to pay/actual payment.
} 


\section{Box 2. Measurement of Domestic Government Arrears}

1. An amount in arrears is usually understood as the amount owed but not paid by the government. The question remains as to from what date the government owes the money.

2. Government debt is legally binding once the goods or the services ordered have been delivered, that is, the liquidation phase. The simple fact of placing an order does not commit the government to paying, or constitute arrears if the payment is not made.

3. Arrears are incurred when the ordered goods or services have been delivered (liquidation phase), but the order to pay has not been given by the credit manager to the public accountant (a case of "administrative or technical" arrears), or when the accountant is unable to execute an order to pay, owing to a lack of cash (a case of real arrears).

4. Even when cash is available for payment, spending procedures normally require time to be completed; hence, everything due but not paid is not automatically an arrear. ${ }^{1}$

Salary payment goes through a different channel (payments are usually made as long as the work contract is valid). In France, any claim on government which is unpaid within four years becomes void, unless the creditor launches a lawsuit before the end of that period.

${ }^{1}$ In this regard, the WAEMU stipulates that current arrears are orders to pay not honored within 90 days; during those 90 days, expenditures are in the administrative pipe and are considered a "float."

\section{Strict Segregation of Duties Between Credit Managers and Accountants}

The four phases of the spending process also specify a segregation of duties between those who administer budget appropriations and those who actually manipulate cash. The first three functions (origination, validation, and order to pay) are carried out by the ordonnateurs (those who give the order to pay), whereas the last one is carried out by the comptable or public accountant (payment phase). One advantage of this segregation of duties is that it establishes a mechanism of mutual control between those who commit the government (an administrative decision without cash manipulation) and those who make the actual payment (actual manipulation of cash). Moreover, as the accountants are placed under the finance ministry's authority, the latter can better monitor spending by the government agencies, through the controls performed by those accountants on public expenditures.

However, the overarching rule of the French PEM system is subject to two main exceptions: government secret funds (fonds spéciaux), which the government does not have to justify, usually related to national security matters; and cash advance funds (régies d'avances) which for practical reasons are designed to remedy the lengthy spending procedures, if the need to swiftly use government funds arises in well-defined circumstances. The typical case is the payment of petty cash expenses. 


\section{Control of Budget Execution}

The three types of budget control include administrative control by the administration's internal bodies, parliamentary control exercised by Parliament, and jurisdictional control carried out by the Public Audit Office (Cour des Comptes). Box 3 summarizes the nature and scope of these different types of control.

\section{Box 3. Types of Budget Control}

\section{Administrative control}

The controls operated by the financial controller at the origination phase of the spending process (engagement), and by the accountant at the payment phase (paiement) are typical examples of administrative control. Spending ministries also have their internal control bodies which belong to this category of control. The chief objective of those controls is to check compliance with laws and regulations that govern the use of public money.

The Inspection Générale des Finances (IGF) is the control arm of the finance ministry, but it covers the entire public sector (noteworthily, it also controls the central bank and the social security system), although in practice the focus is put more on deconcentrated government units and other entities benefiting from public funding.

Administrative control is an internal control.

\section{Parliamentary control}

The control prerogatives of Parliament are defined by the Constitution. Parliament authorizes the use of public money by the executive branch through the vote of the initial budget law (loi de finances initiale). Only another law, namely a supplementary budget law (loi de finances rectificative), can modify the initial authorization. Also, another budget law, the budget review law (loi de règlement) certifies that the budget has been executed in conformity with prior legislative authorizations.

Besides those three modes of control through a formal vote, Parliament can also set ad hoc committees to investigate any misuse of public money by the executive branch.

Parliamentary control is an external control.

\section{Jurisdictional control}

The Public Audit Office (Cour des Comptes) is an independent jurisdiction from both the executive and legislative branches of government. Its attributes are defined by the Constitution. The scope of its investigations has evolved over time: it performs financial audits (accounts held by the public accountants) , as well as performance audits (observance of the principles of economy, effectiveness, and efficiency in the use of public money). In addition to government accounts, the Public Audit Office also audits agencies benefiting from government funding.

Established by the Law of September 16, 1807, the Public Audit Office has no control over credit managers. The office judges the accounts, not the accountants.

The control exercised by the Public Audit Office is also an external control. 


\section{E. Some Questions About the Traditional French PEM System}

\section{Are expenditure controls redundant?}

The a priori control exercised by the financial controller at the very early stage of the spending process (engagement or origination), if properly performed, constitutes a key proof of the integrity of the PEM system. Indeed, once the goods or services are delivered (liquidation or validation phase), the government becomes legally liable and it then is too late to repudiate the government's commitment. Therefore, the insistence on checking compliance with spending rules at the very beginning of the process is justified.

Similarly, the control performed by the accountant, which at first might appear redundant (the accountant checks again what has been already checked by the financial controller) is meant to further secure the integrity of the spending chain. This redundancy in controls is consistent with the principle of strict segregation of duties between those who order goods and instruct the accountant to pay, and the accountants who disburse cash. In effect, the accountant does not intervene in the administrative phase of the spending process (origination, validation and order to pay); therefore, it makes sense to double-check before paying, especially as the accountant incurs an unlimited personal liability in case of error or misdeed. The ordonnateur does not carry such a liability. Furthermore and rarely noted, the sheer number of origination acts can be overwhelming for just one financial controller to oversee thoroughly. Consequently, it is a good thing that the accountant takes a second look at the payment orders.

\section{Ambiguities of the function of the financial controller}

From a hierarchical standpoint, the financial controllers belong to the Budget Directorate (within the finance ministry). They are posted in different spending ministries and government agencies, to monitor observance of sound spending procedures. They intervene in particular at the origination and payment-order levels. The financial controllers do not judge the relevance (opportunité) of a spending, but only its compliance with established rules and regulations. As finance ministry correspondents in the spending agencies, they control over the spending process and report to the finance minister a . In that capacity, they are prime interlocutors of the Public Audit Office and Parliament in case of an investigation. On the other hand, they act as advisers to the host ministers. As a fact, financial controllers have a say in important financial decisions made by the host ministry. Moreover, in their annual reports, they can make proposals for improvement of the spending process. The financial controller both controls and advises the host minister.

\section{Does a strong ex ante control compensate for a weaker ex post control?}

The a priori controls in the first (origination) and last (payment) phases of the expenditure process are key features of the integrity of the French PEM system. Conversely, the control of the executed budget by Parliament remains largely symbolic. In effect, Parliament only validates the reconciliation of the accounts that has already been carried out in two steps: the ACCT (account-centralizing body within the finance ministry) has checked consistency 
between accounts held by individual accountants and the consolidated government accounts on the one hand (General Declaration of Conformity), and on the other hand, the Public Audit Office has reconciled the administrative accounts held by credit managers but not involving cash manipulation, and the accounts held by the accountants who pay on government behalf. More important, a thorough audit of consolidated government accounts by the Public Audit Office, in the form of a detailed verification of accounts, occurs with a three-to-five-year lag. For the sake of efficiency, the Public Audit Office audits only selected agencies every year.

\section{Unlimited responsibility of public accountant versus quasi-immunity of ordonnateur}

A public accountant is personally and financially responsible for any irregularities that might occur in the management of the funds he is entrusted with. In a sharp contrast, the responsibility of those who administer credits and give orders to pay (ordonnateurs) is not well defined. In that connection, ministers and elected local officials are not subject to the Budgetary and Financial Discipline Court. ${ }^{8}$ Indeed, ministers cannot be tried by the court, but the members of their cabinets and other civil servants can be subject to legal prosecution. This poses an interpretation problem when a civil servant acts on behalf of his minister. Fully establishing ministerial responsibility should also consist in questioning the relevance of ministers' decisions to spend, besides the procedural and legal irregularities they may have committed. The sanction by the court is first and foremost a moral one, and the cost is mainly reputational. Indeed, an adverse judgment does not automatically repair the financial prejudice inflicted by the wrongdoer, as the sanction can reach at most two months of his salary as a civil servant. In reality, the court is largely dormant. ${ }^{9}$

\section{COMPARING FrenCH AND AFriCAN PEM Systems}

\section{A. Overall Comparison}

Each country of the sample is compared to the French system in each of the 46 PEM questions in the questionnaire [see appendix II]. To that end, a binary scoring was adopted on every question $(1=$ similar and $0=$ different $)$. Then, to build a similarity index for each of the 6 PEM subcategories described earlier, a country's total scoring was computed on a scale from 0 (different from France) to 1 (identical to France). Basically, the total scoring is the number of positive occurrences (scoring1) divided by total number of questions:

\section{Score $=$ Number of similarities $/$ Number of items}

The scoring does not involve listing PEM systems from the best to the worst. It determines only which PEM system is the closest to the French model. Indeed, no judgment is

\footnotetext{
${ }^{8}$ The court was established in 1948.

${ }^{9}$ The court comprises magistrates of the Public Audit Office and members of the State Council (Conseil d'Etat), appointed by the executive branch for a five-year term.
} 
pronounced as to whether the reference model itself is good or bad. Also, as already mentioned, "reference model" means the historical reference, not a prescribed performance benchmark.

The statistical output lists countries from the closest to the farthest from the French model (in parentheses the overall similarity index) as follows: Benin (0.74); Côte d'Ivoire and Mali (0.72); Burkina Faso, Niger, and Senegal (0.70); Madagascar (0.67); Cameroon (0.65); Chad (0.63); Guinea 0.61); the Republic of Congo and Togo (0.57). The figure below illustrates the comparisons.

Figure 1. Overall Similarity to France (at End of 2001)

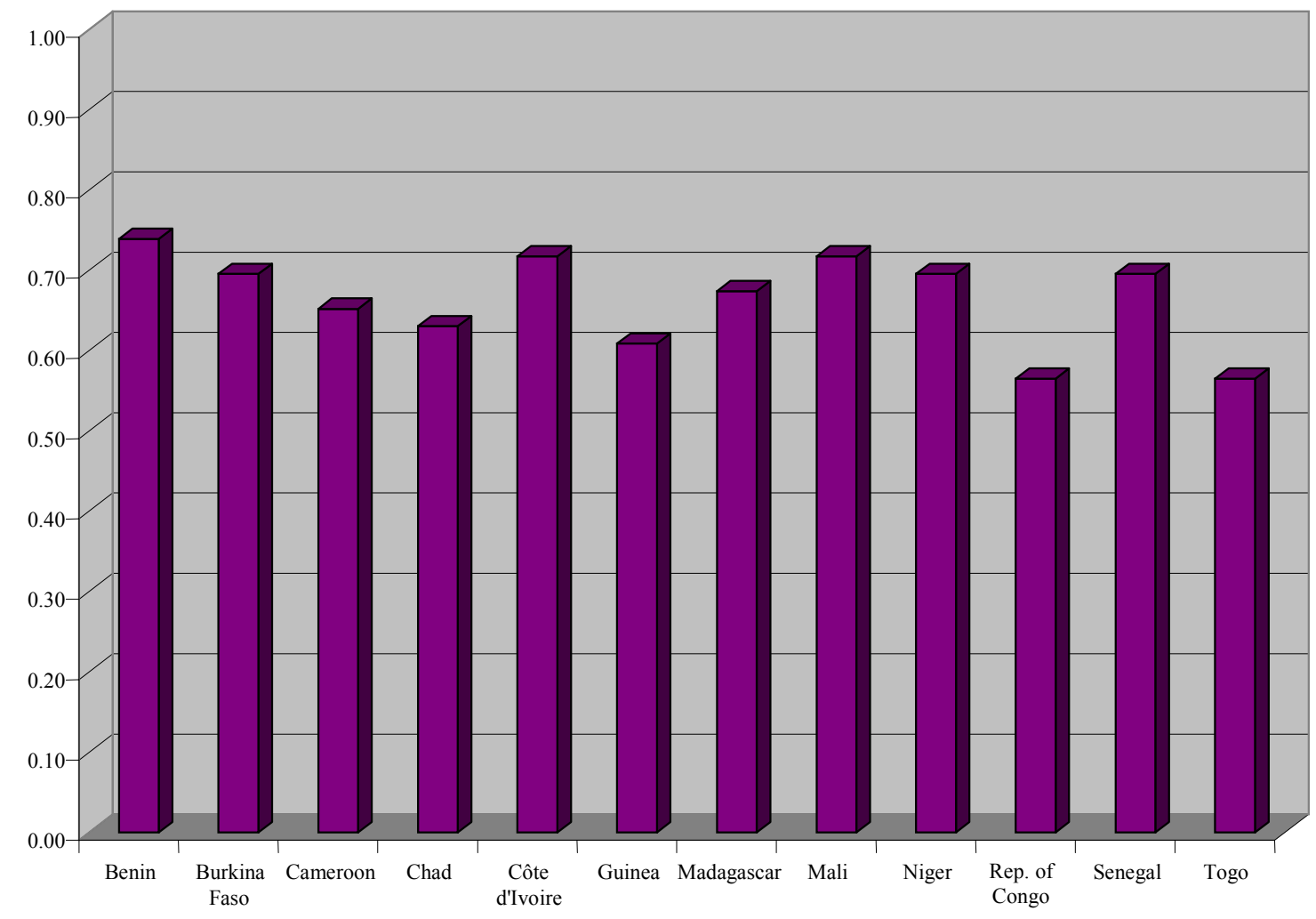

Source: Author's computations based on responses to questionnaire.

Note: The $\mathrm{Y}$ axis describes the similarity index ranging from 0 to 1 .

The following conclusions can be drawn from Chart 1:

- $\quad$ African countries in the sample roughly share 57 percent to 74 percent of the PEM features (as specified in the 46 questions) with the reference model;

- $\quad$ Benin is the closest to France, the reference model, followed by Côte d'Ivoire and Mali; 
- $\quad$ The Republic of Congo and Togo reflect the greatest differences from the reference model; and

- $\quad$ Except for Togo, WAEMU countries are closer to the reference model than other countries.

\section{B. Comparisons on PEM Subcategories}

All in all, the similarity between the French system and the systems of the African countries is very strong regarding the cash plan and description of expenditure process and internal control. Differences are marked on audit and external control, and accounting and reporting systems.

\section{Description of legal and institutional environment}

African countries are similar to France in the legal and institutional aspects of budgeting (similarity index above 0.8 ), such as the reference to the government, the parliament, and control institutions; the control of the government by the parliament, through the vote of the budget law, the supplementary budget review laws, and the budget review law; and the adherence to a deadline for the formulation and execution of the budget.

The countries are very different from France (similarity index close to 0 ) regarding the nature of the ordonnateur and in the degree of budget consolidation. In general, African countries have a more centralized structure with an ordonnateur unique, who is often part of the finance ministry (an ordonnateur is the authority which gives the order to pay), while in France, all ministers are ordonnateurs for their ministries' spending. Budget consolidation is very weak in Africa (where often only the central government's operations are recorded), but this is not the case in France

\section{Existence of fiscal rules}

Both in African countries and in France, government borrowing from the central bank is always governed by law. By contrast, fiscal rules such as the budget deficit target, the capping of government borrowing, the strict limitation of government recourse to commercial banks, and the existence of rules governing the use of state borrowing, although frequent in Africa, are not generalized.

\section{Description of the expenditure process and internal control}

There is convergence in the largely normative PEM aspects described in the budgeting laws, rules, and regulations. The Francophone countries are similar to France (similarity index above 0.8) with regard to: (1) their expenditure processes following the engagement / liquidation / ordonnancement / payment phases; (2) the a priori control exercised by the financial controller (under various names according to countries) at the spending origination level or engagement; (3) the a priori control performed by the public accountant before disbursing money, by verifying compliance with budget rules and payment procedures; 
(4) the segregation of duties between the ordonnateur who gives the order to pay and the accountant who actually pays; (5) the deadline for committing government and ordering payment during a fiscal year; (6) the fact that government debt is incurred only after the delivery of the goods or service (liquidation phase); and, (7) expenditure procedures simplified for petty cash spending (i.e., the existence of régies d'avance), with spending through the régies limited to specific items and the amount to be spent capped.

Reflecting the common antecedents, the differences between France and African countries are minor in subcategories described above.

\section{Accounting and reporting systems}

There is also considerable similarity between France and francophone countries (index above 0.8 ) concerning double entry accounting and the existence of a mix of cash and accrual accounting. No country has so far moved to a full accrual system, not even France.

However, there are important differences in the area of budget classification: while France has an administrative, economic, and a functional classification, progress made in the adoption of a functional classification varies from one African country to another. Benin and Mali are using such a classification, whereas Burkina, Cameroon, Niger, and the Congo have only introduced administrative and economic classifications.

\section{The most striking differences (similarity index equal to 0 ) exist regarding fiscal} reporting and budget computerization: consolidated Treasury balances are neither frequent nor timely; also, budget construction is partly manual in most African countries. In many, the periodicity of the TOFE (government fiscal table) is monthly, except for Senegal, which has a quarterly TOFE. ${ }^{10}$ However, the time lag between the publication date and the period covered frequently amounts to 60 days; in this regard, Burkina Faso, Côte d'Ivoire and Madagascar are notable exceptions, with TOFEs produced between 15 to 30 days after the closing period.

\section{Cash plan}

In almost every case (similarity index close to 1), a government cash plan exists and is updated on a monthly basis.

\section{Audit and external control}

This subcategory illustrates the greatest divergence between francophone countries and the reference model (the similarity index is 0 or close to 0 ). The supreme audit institutions are either quite recent in many African countries or they do not exist. In practice, government auditors are generally not independent from the executive branch. Auditors'

\footnotetext{
${ }^{10}$ It is worth noting that WAEMU recommends only a quarterly TOFE, although a monthly one is preferable.
} 
recommendations are rarely implemented. Generally in Africa, only financial audits, not performance or management audits, are carried out. In francophone Africa, government accounts are rarely verified by the supreme audit institution. In countries like Chad, Cameroon, ${ }^{11}$ and Togo, the accounts have never been verified; in the latter two, no public audit office existed at end-2001, in spite of a constitutional provision mentioning such an office. In cases like that of the Republic of Congo, the Chamber of Accounts formally exists but is not operational. Also, in the best case, executed budgets are published with very long delays amounting to years (generally, more than five years after their closing date).

Figure 2. Similarity to France by PEM Subcategories (at End of 2001)
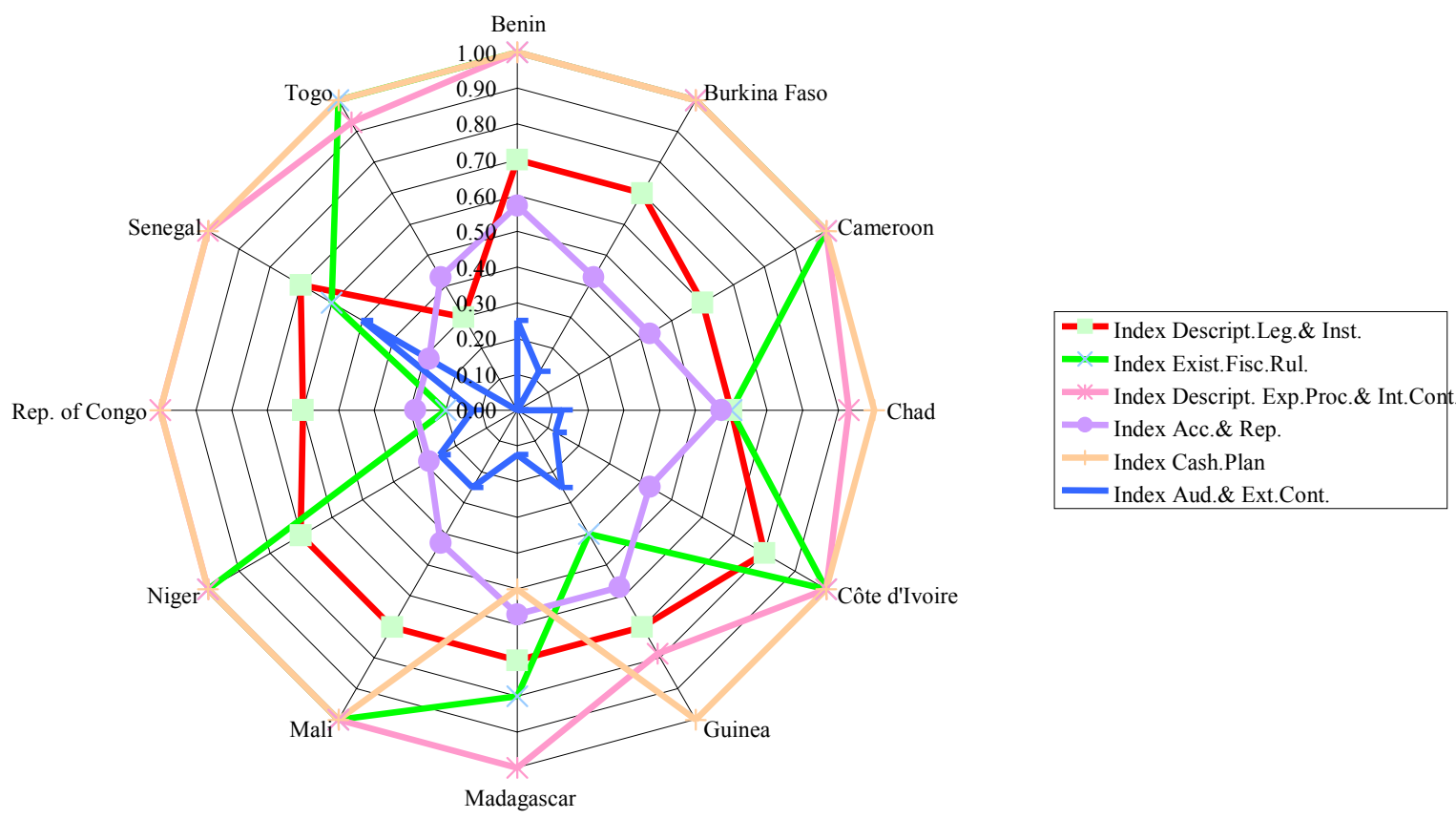

Source: Author's computations based on responses to questionnaire.

Note: Figures represent similarity indices, ranging from 0 to 1.

This above chart describes the similarity of African countries to France in each of the six PEM subcategories previously defined: the closer to the center of the figure, the more different; the further, the more similar. It clearly appears that differences with the reference model are more pronounced for audit and external control on the one hand, and on accounting and reporting systems for the other.

\section{The distance between theory and reality in African countries}

\footnotetext{
${ }^{11}$ In Cameroon, a ublic audit office has been created in May 2003, but it is not operational.
} 
Although they matter a great deal, well-designed institutions do not constitute a panacea. Budget formulation, execution, and control measures suggest a degree of smooth cooperation among branches of government, but this is not always guaranteed. In this regard, adequate institutions (e.g., a public audit office) are lacking or are totally inefficient. Human behavior is also a key parameter. As a fact, it is of paramount importance that public financial managers abide by the rules they have themselves set. Delays in the preparation of the budget law and in the execution of the budget attest to the difficulty in complying with the budget calendar (closing of commitments, of payment orders and of disbursement). Long delays are observed in voting the budget review laws (e.g., Burkina and Senegal). This results in an undue extension of the complementary period (Burkina, Senegal, Niger, and Togo). The unification of current and capital budgets is not always achieved (i.e., entities in charge of current and capital spending often work separately, as in Burkina Faso and Togo). Moreover, recurrent costs incurred by capital spending are generally poorly accounted for. There is a lack of consolidated general government data.

Furthermore, in many countries, the information flow between the budget directorate and the treasury is not regular. The treasury feedback to budget directorate concerning the actual payment of payment orders is not systematic, generating difficulties in monitoring the real level of arrears (payment orders which have not been honored) and in managing government cash (if payment difficulties are known in time, the pace of commitments can be slowed down to accommodate cash constraints). The reconciliation of treasury and central bank data is also a problem, reflecting mainly government's accounting and consolidation difficulties. While monetary data are generally reliable, those of the Treasury are often incomplete or incorrect, as a result of a poorly monitored budget execution.

With regard to the description of the expenditure process and internal control, in practice the normal budget process is often bypassed and recourse to exceptional spending procedures is widespread (i.e., régies d'avance, paiements par anticipation). Spending rules are easily circumvented. Extrabudgetary spending is common, and political interference in the decision to spend is strong. Expenditure costing is poor, particularly with regard to utility bills (e.g., water, electricity and telephone). The control systems are generally cumbersome and inefficient. The false idea that the multiplication of controls improves control tends to prevail; quite the opposite occurs in reality. The length of the administrative spending process and the lack of efficient control make it difficult to evaluate the real level of payment arrears.

On the accounting and reporting side, besides the delays in producing consolidated treasury balances and TOFEs (government fiscal tables), the reliability of fiscal data is often questionable. Discrepancies between TOFEs and balances (the former is supposed to derive from the latter) are sometimes substantial, and the publication periods do not always coincide. In the government fiscal tables, treasury special and correspondent accounts (when they exist) and domestic nonblank financing data show incorrect amounts. The monitoring of debt data can also be improved. In the absence of feedback on past executed budgets (role of the budget review laws and audit offices) and in the presence of weak revenue and 
expenditure-forecasting tools, fiscal figures are not reliable. The very exercise of budget forecasting is not conducted in an appropriate way.

Moreover, audit and external control are the weakest links of the African PEM systems. When they exist, the public audit offices (cour de comptes) are ill-equipped and lack an adequate number of skilled staff members, ${ }^{12}$ except for Senegal (which has more than 50 agents). In reality, government accounts are rarely audited or published, and audit recommendations are not implemented.

Countries in Western Africa expect a lot from the WAEMU Directives. These directives were supposed to be implemented in 2002, but countries are adopting them at different paces and with delays. While the directives give guidance with regard to critical fiscal areas (i.e., an organic budget law, budget nomenclature, chart of accounts, fiscal tables or TOFEs, and fiscal transparency), their internal consistency needs to be enhanced (e.g., on the complementary period) and their soundness is sometimes questioned (e.g., on budget nomenclature). The directives' main goal is to harmonize fiscal management within the union (respect of convergence criteria); the imposition of a unique budget law on all countries regardless of their legal and institutional background or capabilities should be avoided.

\footnotetext{
${ }^{12}$ In most countries, the public audit office has had fewer than 10 staff members.
} 


\section{Box 4. Testing Reliability of Budget}

The fairness of revenue and expenditures projections can be tested through the following criteria:

- Presumption: Does the existing institutional arrangement allow good budget preparation, execution, and control? Is the parliament actively and critically involved in the vote of the initial, supplementary, and review budget laws, or is the vote a pure formality? Is the public audit office independent and are the government accounts verified on a regular basis? Does the country have human, administrative, and technical capacity to properly prepare and implement budgets? If the answers to those questions are positive, then chances are high that the budget has meaning and relevance.

- Practice and record: What do we learn from past budgets? Is the budget calendar observed? How are revenue projections made (e.g., macro assumptions)? What is the methodology for expenditure costing (e.g., the utilities bill)? Are budget review laws voted on a regular basis? With hindsight, have the projections been close to outturns?

- Transparency and public scrutiny: Are budget data published and accessible to the general public? Can and does the general public critically examine the budget?

The vast majority of African countries fail some or all of the above tests. Indeed, although they exist on paper, institutions work very poorly in practice. The parliament budgetary role remains very weak. The public audit offices are notoriously understaffed; they lack adequate material means. More importantly, they are rarely independent from the executive branch. Countries' technical skills are limited, in particular in the area of forecasting (macro assumptions underlining budget figures); the computerization of government financial operations is still at its early stage in most countries. In the absence of regular budget review laws which shed light on budget execution figures, little feedback is given on the implementation of past budgets. Revenue forecasts are often "voluntarist" (i.e., politically motivated). 


\section{Most Divergent Individual PEM Questions}

Besides the overall comparison and comparison on PEM subcategories, twelve specific PEM questions (the chart below indicates the questions ${ }^{13}$ ) show striking differences between the French model and the surveyed African countries. In all the surveyed African countries, except for Madagascar, where line ministries give the order to pay as in France, the role of the finance ministry is overwhelming. It has the monopoly, often through the budget directorate, in giving the order to pay (via the ordonnateur principal unique). Only in Côte d'Ivoire does budget consolidation incorporate autonomous government establishments as in France; elsewhere the budget principally refers to the central government budget. A treasury single account does not exist in any of the surveyed African countries. No African country produces a fiscal summary on a weekly basis. While it is a matter of days in the French model, the lag between the date of production of the consolidated treasury balance and its reference period is much longer in African countries (at least one month). The budget is constructed semi manually in all the African countries, while it is fully computerized in France. Among African countries, only Senegal has a full-fledged public audit office (cour des comptes). Senegal's Public Audit Office is the only one to display some degree of independence vis-à-vis the executive branch, but even here, it very much depends on the sensitivity of the investigations. When an audit body exits in the surveyed African countries, its recommendations are rarely or never implemented. Where an audit body exists in the surveyed African countries, it performs only financial audit, not performance audit. Contrary to France, the surveyed African countries verify their accounts in detail four to five years after their closing, at the earliest. Last, budget outturns are published seven to 12 months after the fiscal year in the best cases; in many cases, they are never published.

\footnotetext{
${ }^{13}$ The 12 most divergent questions are: $Q 13 ; Q 15 ; Q 16 ; Q 40 ; Q 41 ; Q 42 ; Q 45 ; Q 46 ; Q 48 ; Q 53 ; Q 54 ; Q 55$. $Q 17$ to $Q 21$ relate to fiscal rules; $Q 22$ to $Q 35$ deal with the expenditure process and internal control; $Q 36$ to $Q 42$ describe the accounting and reporting system; $Q 43$ and $Q 44$ relate to the cash plan; and $Q 45$ to $Q 55$ deal with audit and external control.
} 
Figure 3. Similarity Index to France, by Individual Questions

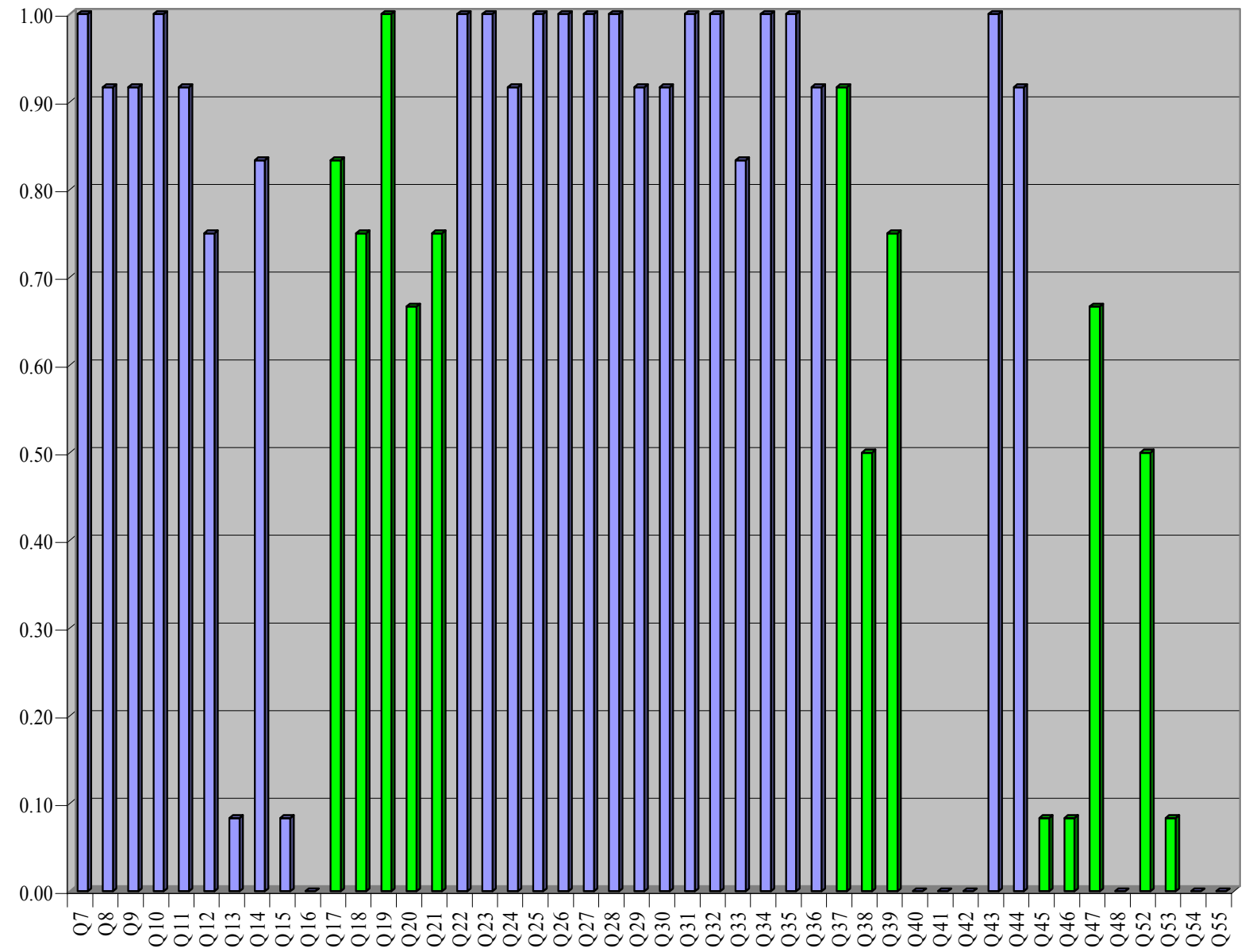

Source: Author's computations based on responses to questionnaire.

Notes:

The $\mathrm{X}$ axis refers to individual questions relating to public expenditure management.

The $\mathrm{Y}$ axis describes the similarity index by question, ranging from 0 to 1 . 


\section{COMParing AFrican COUnTRIES}

\section{A. Overall Comparison}

Pearson correlation coefficients ${ }^{14}$ are used to obtain a measure of the similarity or proximity between each pair of countries, ${ }^{15}$ using the French system as a yardstick for comparisons.

Data on countries were recoded so that the answer to each single country was transformed into a score against a predetermined reference (here, degree of compliance with the French system, measured by dummies 1 and 0 on each specific question). The objects (countries) were measured on 46 variables (questions). The traditional objects (x) variables matrix is inverted, so that the columns represent the objects and the rows the variables. As a result, the correlation coefficient between two countries measures the similarity between the two countries with respect to the set of PEM 46 questions. The higher $r$, the closer the pair of countries. The resulting correlation matrix ${ }^{16}$ helps identify how similar or close (higher $r$ ), or how different (lower $r$ ) countries are, compared two by two.

14 The correlation coefficient is given by the formula:

$$
r=\frac{\sum\left(x_{i}-\bar{x}\right)\left(y_{i}-\bar{y}\right)}{(n-1) S_{x} S_{y}}
$$

where

$\left(x_{i^{-}} \bar{x}\right)$ is the deviation on an individual object's value on the $\mathrm{x}$ variable from the mean of that variable;

$\left(y_{i}-\bar{y}\right) \quad$ is the deviation of that object's value on the y variable from the mean of that variable;

$S_{x}$ and $S_{y}$ are the sample standard deviations on the x and y variables;

$n$ is the number of pair of observations;

$\sum$ is the summation the $i=1,2, \ldots . . n$ pairs.

${ }^{15}$ See Kachigan, 1986, Statistical Analysis: An Interdisciplinary Introduction to Univariate and Multivariate Methods (New York: Radius Press).

${ }^{16}$ The number $N$ of unique correlation coefficients in a correlation matrix based on $k$ variables is given by the formula $N=\left(k^{2}-k\right) / 2$. A sample of 12 countries will thus generate 66 correlation coefficients. 
Table 1. Correlation Matrix

\begin{tabular}{|l|l|l|l|l|l|l|l|l|l|l|l|l|}
\hline Ben. & 1 & & & & & & & & & & & \\
\hline Burk & 0.898 & 1 & & & & & & & & & & \\
\hline Cam & 0.813 & 0.906 & 1 & & & & & & & & & \\
\hline Chad & 0.776 & 0.668 & 0.670 & 1 & & & & & & & & \\
\hline Cong & 0.677 & 0.659 & 0.649 & 0.782 & 1 & & & & & & & \\
\hline C.Iv & 0.837 & 0.739 & 0.758 & 0.720 & 0.618 & 1 & & & & & & \\
\hline Guin & 0.741 & 0.631 & 0.537 & 0.678 & 0.645 & 0.585 & 1 & & & & & \\
\hline Madg & 0.748 & 0.749 & 0.660 & 0.716 & 0.606 & 0.593 & 0.487 & 1 & & & & \\
\hline Mali & 0.947 & 0.844 & 0.758 & 0.720 & 0.618 & 0.893 & 0.684 & 0.696 & 1 & & & \\
\hline Nig & 0.854 & 0.850 & 0.855 & 0.716 & 0.700 & 0.799 & 0.583 & 0.604 & 0.799 & 1 & & \\
\hline Sen & 0.575 & 0.589 & 0.608 & 0.570 & 0.659 & 0.634 & 0.438 & 0.447 & 0.634 & 0.649 & 1 & \\
\hline Tog & 0.677 & 0.754 & 0.833 & 0.510 & 0.649 & 0.618 & $0.375^{*}$ & 0.512 & 0.618 & 0.700 & 0.468 & 1 \\
\hline & Ben & Burk & Cam & Chad & Cong & C.Iv & Guin & Madg & Mali & Nig & Sen & Tog \\
\hline
\end{tabular}

Source: Author's computations based on responses to questionnaire.

Notes:

Correlation is significant at 0.01 level (2-tailed).

*: Correlation is significant at 0.05 level (2-tailed).

The countries include Benin, Burkina Faso, Cameroon, Chad, Republic of Congo, Côte d'Ivoire, Guinea, Madagascar, Mali, Niger, Senegal and Togo.

From Table 1, it can be concluded that:

- Assuming $r=0.6$ is a cut-off point, ${ }^{17}$ the correlation among African countries is generally significant $(r>0.6)$; in light of generally strongly correlated pairs of countries, one can legitimately talk of francophone Africa PEM systems that share many common features. However, no clear clusters appear.

- $\quad$ Benin and Mali on the one hand, and Burkina Faso and Cameroon on the other, look very much alike $(r>0.9)$ in their compliance with France on each single question; and

- $\quad$ There are marked opposites such as Madagascar/Guinea, Senegal/Guinea, Togo/Guinea, Togo/the Congo, and Togo/Senegal (smaller $r$ in those cases).

\section{B. Comparison of PEM Subcategories}

The coefficient of dispersion ${ }^{18}$ is used to measure dispersion among African countries on PEM subcategories, from the scores (indices) on PEM subcategories. Table 2 shows the results of computations:

${ }^{17}$ Usually, a correlation coefficient of 0.6 and above denotes a strong association.

${ }^{18}$ Assuming $\bar{x}$ is the mean and $S_{i}$ the standard deviation on a specific subcategory, then the coefficient of dispersion is given by the formula

$$
\text { Coefficient of dispersion }=\bar{x} / S_{i}
$$

(continued) 
Table 2. Dispersion Among African Countries in PEM Subcategories

\begin{tabular}{|l|c|c|c|c|c|c|}
\hline & $\begin{array}{c}\text { Descript. } \\
\text { Leg. \& Inst. }\end{array}$ & $\begin{array}{c}\text { Exist. } \\
\text { Fisc.Rul. }\end{array}$ & $\begin{array}{c}\text { Descript. } \\
\text { Exp.Proc. \& } \\
\text { Int.Cont }\end{array}$ & $\begin{array}{c}\text { Account. \& } \\
\text { Report. }\end{array}$ & Cash. Plan & $\begin{array}{c}\text { Aud. \& } \\
\text { Ext.Cont }\end{array}$ \\
\hline Benin & 0.70 & 1.00 & 1.00 & 0.57 & 1.00 & 0.25 \\
\hline Burkina & 0.70 & 1.00 & 1.00 & 0.43 & 1.00 & 0.13 \\
\hline Cameroon & 0.60 & 1.00 & 1.00 & 0.43 & 1.00 & 0.00 \\
\hline Chad & 0.60 & 0.60 & 0.93 & 0.57 & 1.00 & 0.13 \\
\hline Côte Ivoire & 0.80 & 1.00 & 1.00 & 0.43 & 1.00 & 0.13 \\
\hline Guinea & 0.70 & 0.40 & 0.79 & 0.57 & 1.00 & 0.25 \\
\hline Madagascar & 0.70 & 0.80 & 1.00 & 0.57 & 0.50 & 0.13 \\
\hline Mali & 0.70 & 1.00 & 1.00 & 0.43 & 1.00 & 0.25 \\
\hline Niger & 0.70 & 1.00 & 1.00 & 0.29 & 1.00 & 0.25 \\
\hline Congo, Rep. & 0.60 & 0.20 & 1.00 & 0.29 & 1.00 & 0.13 \\
\hline Senegal & 0.70 & 0.60 & 1.00 & 0.29 & 1.00 & 0.50 \\
\hline Togo & 0.30 & 1.00 & 0.93 & 0.43 & 1.00 & 0.00 \\
\hline \multicolumn{1}{r}{ Mean } & 0.65 & 0.80 & 0.97 & 0.44 & 0.96 & 0.18 \\
\hline $\begin{array}{c}\text { St.Deviation } \\
(B)\end{array}$ & 0.12 & 0.28 & 0.06 & 0.11 & 0.14 & 0.14 \\
\hline $\begin{array}{c}\text { Coeff.Disp. } \\
{[(B) /(A)]}\end{array}$ & 0.19 & 0.35 & 0.07 & 0.26 & 0.15 & 0.76 \\
\hline
\end{tabular}

Source: Author's computations based on responses to questionnaire.

Note: The countries include Benin, Burkina Faso, Cameroon, Chad, Republic of Congo,

Côte d'Ivoire, Guinea, Madagascar, Mali, Niger, Senegal, and Togo.

Table 2 shows that:

- African countries are particularly dispersed on audit and external control questions, which have the highest dispersion coefficient (0.76);

- $\quad$ The existence of fiscal rules is the second most important subcategory of dispersion;

- The description of expenditure process and internal control is the subcategory with the smallest dispersion (coefficient $=0.07$ ), thus indicating that differences are minimal among countries in that area; and

- $\quad$ Except for Madagascar, all the countries have a monthly cash plan updated on a monthly basis.

Where $S_{i}=\sqrt{\frac{\sum(x-\bar{x})^{2}}{n}}$ 


\section{Technical Assistance Policy Implications and Conclusions}

\section{A. Main Lessons Drawn from Study}

From the study, it appears that:

- $\quad$ Although they historically borrowed heavily from the French budgeting system for the design of their PEM systems, francophone African countries have departed from the original model in practice. In particular, they imported it without the matching institutional, human, and technical capacities.

- Although similarities to the French system are strong on the normative side (what is supposed to be done), such as the legal and institutional framework or the raw description of the expenditure process and internal control procedures, differences between the French system and those of the African Francophone countries are striking when it comes to the positive side (what is actually done, in measurable and verifiable terms). The monopoly held by the ministry of finance (MOF) in giving payment orders is a distinctive feature of African PEM systems, as is the weaker budget consolidation. African accounting and reporting systems, and audit and external control differ widely from those of the reference model. Indeed, the periodicity and timeliness of fiscal summaries, the publication of government accounts, the type of budget classification in place, and the work of the supreme audit institutions clearly differ between the French PEM system and those of francophone African countries.

- $\quad$ Although they share many PEM features (generally high correlation coefficients on the basis of the 49 PEM questions), African countries also differ among themselves, as evidenced by varying levels of correlation between pairs.

\section{B. Challenges and Policy Decisions for African Countries}

\section{Does French PEM system suit Francophone Africa?}

The existing French budgeting system was largely shaped by the 1959 Ordinance on Budget Law and the 1962 Decree on Public Accounting, which corresponded to France's particular needs at that specific moment in its history. After experiencing the collapse of the state during the Second World War and parliamentary instability during the Fourth Republic, France wanted a strong executive branch (the 1958 Constitution provides that the executive branch defines and conducts the national policy; ${ }^{19}$ also, the executive branch can bypass parliament on budget matters, in specific exceptional circumstances). ${ }^{20}$

\footnotetext{
${ }^{19}$ Article 20 of the Constitution.

${ }^{20}$ For example, Article 47 regarding delays in the vote of the budget by parliament.
} 
After gaining their independence in early 1960, many French-speaking African countries gradually adopted the former colonial power's budgeting system shaped by its 1959-62 legislation. The budgeting systems which had prevailed in the colonies were generally rudimentary but sturdy and well-suited to meeting the territories' limited needs. African countries have progressively tried to move even closer to France's budgeting system. The irony is that although African countries are still referring to their French legacy, France itself is moving toward a new budgeting system. The multiplication of controls in the different PEM phases is consistent with French legal and administrative formalism, and with the capacity of its public administration. The quasi-immunity of the ordonnateurs perhaps mirrors the country's reluctance to question political authority. The ongoing reform of the budgeting system (the new Organic Budget Law) is just another illustration of how irrelevant any African efforts to catch up with the French reference model might be. Reference to the French PEM system is historical, not dictated by necessity. Consequently, budgeting rules should be consistent not only with the historical, institutional, and legal context of each country, but also with its administrative and implementation capacities and means. African countries need to devise a budgeting system tailored to their specific needs. In that vein, the focus should shift from sophistication in design to robustness in practice.

\section{PEM weaknesses: a francophone problem or an African problem?}

As was discussed when this study compared French and African PEM systems, while the inspiration for African systems is clearly French, their practice is undoubtedly African (that is, country-specific). The French budget formalism, aimed at safeguarding public funds through sometimes redundant control procedures, has been compounded in Africa with an acute sense of hierarchy and administrative slowness. Flexibility introduced in the French system with regard to the budget calendar (i.e., the complementary period) or exceptional spending procedures (i.e., régies d'avances) has been overused in francophone Africa. The budgetary prerogatives of the parliaments (vote of initial, supplementary, and review budget laws; control of the executive branches) and the control power of the public audits largely remain symbolic, thus ruling out any serious system of checks and balances to offset the powerful executive branches. In some instances, vested interests resist any change and the political will to promote budget reforms is simply lacking. Last but not least, ethical and behavioral aspects of budgeting come to mind: budgeting is not just a technique, and no serious improvement of the PEM systems can be expected from ill-intentioned public managers. As a result, the oft-raised argument about the lack of adequate administrative capacity as the main impediment to budget reform needs to be qualified. Many studies on budgeting in English-speaking Africa highlight weaknesses similar to those diagnosed in the French-speaking countries, ${ }^{21}$ thus corroborating the fact that the PEM flaws described above are typical of not just francophone countries, but rather constitute a more general African problem.

\footnotetext{
${ }^{21}$ Ian Lienert (2003); Alex Sekwat (1997); and Ramakrishnan (1998).
} 


\section{Should African countries, in their current situation, follow budgeting fads?}

Many of the surveyed African countries lack a comprehensive and reliable line-item budget (classification issues, no full integration of current and capital budgets, weaknesses in revenue forecasting and expenditure costing, difficult integration of treasury special accounts, narrow consolidation of government, etc.). The absence of a proper functional classification in many countries makes it difficult to relate outcome to specific inputs; hence, budgeting fads, such as program budgeting, are irrelevant in such a context. The paucity and lack of reliable data constitute another serious hurdle ${ }^{22}$ for performance measurement.

Putting first things first, a good and solid line-item budget is what is most needed at this stage. Similarly, decentralization of PEM has its own perils. It is indeed difficult to decentralize government responsibilities without first ensuring that the central government itself is functioning well and that the lower layers have the required managerial capacities.

\section{Challenges and Policy Decisions for TA Providers}

\section{Which should be priority PEM areas?}

The study clearly points to the need to strengthen two areas where differences between PEM systems in francophone African countries and the reference model are most pronounced: accounting and reporting, on the one hand, and auditing and external control, on the other. This conclusion assumes that the reference model itself is satisfactory, a subject outside the present study. The computerization of government financial management is a prerequisite for an improved accounting and reporting system. The generalization of monthly fiscal tables (TOFEs) and consolidated treasury balances, without long lags between the closing and publication periods of those fiscal summaries, is highly recommended. The reinforcement of external control can be achieved through a more critical involvement of the parliament when it is voting on budget laws (i.e., initial, supplementary, and review laws) and through the creation of truly independent and competent audit offices.

The study does not discuss the sequencing of the measures mentioned earlier. While many such PEM issues are currently addressed by TA providers, little assistance is currently given in external control (the parliament and audit office). In the latter area, the TA role may consist of training members of the parliament in financial and control matters, and helping to design the terms of reference of a public audit office.

\section{Should the focus of TA be national or regional?}

Using the French PEM system as a yardstick, the study showed both convergence and divergence among African countries. While it remains legitimate to speak of a francophone African PEM system, in light of a set of common features, differences among countries are

\footnotetext{
${ }^{22}$ See W. Anderson Williams, "Trusting Numbers: The Power of Data Verification," Government Finance Review, April 2002.
} 
also noticeable on such PEM subcategories as auditing and external control, and the existence of fiscal rules, thus pointing to the need to take account of country specifics. Overall, based of the degree of similarity of surveyed countries to the reference model, the study may suggest that TA should consolidate noticeable progress in countries such as Benin, Mali, Côte d'Ivoire, Burkina Faso, and Niger, while more TA efforts might be needed in countries like the Republic of Congo, Togo, Guinea, and Chad, where weaknesses in PEM seem to be more pronounced. Therefore, TA delivery should have a national focus, and the improvement of PEM system remains a fundamentally national problem.

\section{Conclusion}

In light of the marked differences in practice between the French reference model and African PEM systems, the question arises as to why expenditure management and budgeting in general follow a different pattern in Africa. The lack of human and technical capacities impairs African countries, but other factors, not necessarily belonging to the area of public finances, also matter; these tentatively include the following:

- The lack of institutional continuity. The institutional memory of financial ministries is often flimsy. For instance, the whole accounting system may depend on the presence of a handful of individuals. Reforms sometimes die out as the changeminded people are replaced. Violent political change is the most visible cause of instability: after years of civil war, the Republic of Congo had to rebuild its budget memory, since its fiscal files had been lost or destroyed. Budgeting is essentially a precarious undertaking in an environment characterized by institutional unpredictability.

- $\quad$ The lack of public scrutiny. Public scrutiny with regard to budget matters is at its early stage in Africa, not because of the deterrent aspect of budget intricacies but mainly because information is not made fully available to the public. ${ }^{23}$ Governments often have plenty of discretion in the use of public money and display little accountability. Delays in the voting of budget review laws, the weak parliamentary oversight of budget issues, the paucity of data on past executed budgets, and the absence of external audit of government accounts all point to the fact that fiscal transparency remains a major issue.

- The "privatization" of public finance. Budget choices do not necessarily reflect national priorities, but rather the personal preferences of the ruling class.

- The lack of political commitment and ownership. Budget reforms are seen in countries with no government accountability. They are instituted owing to conditionality imposed by foreign donors, not as a national necessity. Those who are supposed to promote change sometimes end up sabotaging it.

\footnotetext{
23 "Public" should be understood here not as the average person on the street, but rather as special interest groups, political parties, media, and the like.
} 
In Africa, apparently, budgeting and PEM weaknesses reflect an ill-functioning state. The earlier-described institutional constraints and behavioral patterns plead for government building or reform as a prerequisite for sound budgeting and PEM systems.

This study has shown some of the common weaknesses of African PEM systems, but the solutions to those problems do not always belong to the province of public finance.

While this paper presents comparisons between and across countries, it does not provide a basis for performance ratings of individual countries. Such an exercise would involve the establishment of benchmarks, which is not attempted in the present paper. 


\section{PEM QUESTIONNAIRE}

\section{Legal and institutional framework}

Q7. What is the reference made by the Constitution regarding public finance (one choice only):

1. Reference to the government role only.

2. Reference to the government and the parliament roles only.

3. Reference to the government, the parliament and control institutions role.

4. No reference to public finance.

Q8. Is there a Budget Review Law?

1. Yes

2. No

Q9. On budget matters, how does the parliament control the government (one choice only):

1. By voting the only initial finance law

2. By voting the only budget review law

3. By voting finance both the initial and the review budget laws

Q10. Is there any deadline date for the elaboration and execution of the budget?

1. Yes

2. No

Q11. Is there any supplementary budget law to modify the initial finance law in progress?

1. Yes

Q12. Who can decide for the amendment (amount, appropriation...) of the budgetary authorization voted by the parliament?

1. Parliament only.

2. Ministry of Finance (MoF).

3. Parliament and MoF.

4. Spending ministries

5. Other (indicate)

Q13. Who is, according to the texts, the person who issues payment orders in the central government?

1. The Ministry of Finance (or delegation)

2. All ministries managing credits (or delegation)

3. The President of the Republic (or delegation)

4. Others (indicate).

Q14. Budget presentation

1. The budget is a unified document (current and capital budget unified).

2. There are separate current and capital budgets

Q15. Degree of consolidation

1. State budget only.

2. State budget and annex budgets.

3. State budget, annex budget, and the Treasury's special accounts.

4. State budget, annex budget, Treasury's special accounts and accounts for administrative public agencies (EPA).

5. State budget, annex budgets, Treasury's special accounts, EPAs and local governments

Q16. Government accounts in the banks (one choice only) 
1. There is only one Treasury account and it is with the central bank

2. The Treasury has several accounts and sub-accounts in the central bank

3. The Treasury has accounts in the central bank and the commercial banks?

4. Other (indicate).

\section{Existence of fiscal rules}

Q17. Is there any budget deficit target (in \% GDP)?
1. Yes
2. No

Q18. Is there a limit for the debt ratio (in \% of GDP)?
1. Yes

2. No

Q19. Is government borrowing from the central bank governed by a law?
1. Yes
2. No

Q20. Is government borrowing from commercial banks governed by a law?
1. Yes
2. No

Q21. Is there any legal obligation governing the use of government borrowing?

1. Yes

2. No

\section{Description of expenditure process and internal control}

Q22. Does the expenditure circuit follow the cycle of Engagement/Liquidation/Ordonnancement/Paiement?

1. Yes

2. No

Q23. Who has the right to place orders?

1. The Ordonnateur

2. All credit managers

3. Other (indicate).

Q24. Who controls the origination acts (Engagements)?

1. The financial controller.

2. Other (indicate)

Q25. Who gives the order to pay?

1. The Ordonnateur

2. Other (indicate).

Q26. What control procedures do the public accountants perform before paying?

1. Regularity of the expenditures only.

2. Regularity of payment only.

3. Control on the regularity of both the expenditure and the payment

Q27. Are the functions of the person who issues payment orders (Ordonnateur) and the one who pays (Comptable) incompatible?

1. Yes

2. No 
Q28. At which stage of the expenditure process does the control intervene?

1. At the origination stage only (Engagement).

2. At payment orders stage only (Ordonnancement).

3. At the payment stage only.

4. At all stages (origination, payment order and payment).

Q29. Is there any due date to close origination acts (Engagements) during the fiscal year?

1. Yes

2. No

Q30. Is there any due date to close the payment orders during the fiscal year?

1. Yes

2. No

Q31. At which stage of the expenditure cycle does the government debt incur?

1. Origination (Engagement)

2. Validation (Liquidation)

3. Payment orders (Ordonnancement)

Q32. Does the country have Regies d'avance (cash advance system)?

1. Yes

2. No

Q33. Which authority decides for the creation of the Regies d'avance?

1. Ministry of Finance (MOF)

2. MOF and spending ministries

3. Other

Q34. Are the expenditures under the Regies d'avance well-specified?

1. Ministry of Finance.

2. Other.

Q35. Is there an expenditure ceiling, under the system of Regies d'avance?
1. Yes
2. No

\section{Accounting and Reporting System}

Q36. What is the prevailing accounting system?

1. Single entry.

2. Double entry.

Q37. How are budget transactions accounted for?

1. Cash accounting only.

2. Accrual.

3. Mix of cash accounting and accrual accounting.

Q38. What type of budgetary classification prevails?

1. Administrative only.

2. Economic and Economic only.

3. Administrative, economic and functional classification.

4. Other (indicate).

Q39. What is the frequency of the publication of the fiscal table (TOFE)? 
1. Monthly

2. Other (indicate)

Q40. What is the frequency of the production of the treasury's consolidated balance?

1. Daily

2. Weekly

3. Monthly

4. Annually

Q41. Lapse of time between Treasury's balances publication and their period of reference.

1. $10-15$ days

2. Between 15 or 30 days

3. Between 30 to 60 days

4. Beyond 60 days

Q42. Budget is constructed

1. Manually

2. Semi-annually

3. Entirely computerized

\section{Cash Plan}

Q43. Does the government have a cash plan?

1. Yes

2. No

Q44. What is the time period for updating government cash plan?

1. Monthly

2. Quarterly

3. Other (indicate)

\section{Audit and External Control}

Q45. Who verifies the account?

1. The Public Audit Office.

2. A specialized unit of the Supreme Court.

3. The General Inspection.

4. Other (indicate).

Q46. The supreme audit institution or the external control is independent.

1. Yes

2. No.

Q47. Who is legally assigned to launch an audit of a public entity?

1. The ministry of finance only.

2. The parliament only.

3. The institution of the supreme audit itself (self-seized)

4. Various institutions previously cited in 1-2-3.

5. Other (indicate)

Q48. External auditors' recommendations are:

1. Systematically implemented.

2. Often implemented.

3. Rarely implemented. 
Q49. The year of the creation of the supreme audit institution or external control.

Q50. Number of total employees of the supreme audit institution or the external control at the end of 2001.

Q51. How many reports did the supreme audit institution or external control publish in 2002?

Q52. Who is responsible before the supreme audit institution?

1. Public accountants only.

2. Ordonnateurs only.

3. Both public accountants and ordonnateurs

Q53. What types of audits does the external auditor perform?

1. Accounting and financial audit only.

2. Accounting and financial audit, as well as management audit.

Q54. On average, when are the state's accounts verified in detail?

1. One to three years after the closing date.

2. Four to five years after the closing date.

3. More than five years after the closing date.

Q55. On average, when are budget outturns published?

1. In less than 3 months after the closing of the fiscal year.

2. Between 3 or six months after the closing of the fiscal year.

3. Between 7 or 12 months after the closing of the fiscal year.

4. More than twelve months after the closing of the fiscal year. 


\section{LiST OF ABBREVIATIONS}

$\begin{array}{ll}\text { ACCT } & \text { Agent Comptable Central du Trésor } \\ \text { BWI } & \text { Bretton Woods Institution } \\ \text { ELOP } & \text { Engagement / liquidation / ordonnancement / paiement } \\ \text { FAD } & \text { Fiscal Affairs Department, International Monetary Fund } \\ \text { IGF } & \text { Inspection Générale des Finances } \\ \text { IMF } & \text { International Monetary Fund } \\ \text { PEM } & \text { Public Expenditure Management } \\ \text { PRSP } & \text { Poverty Reduction Strategy Paper } \\ \text { TA } & \text { Technical Assistance } \\ \text { TOFE } & \text { Tableau des Opérations Financières de l'Etat } \\ \text { TSA } & \text { Treasury Single Account } \\ \text { WAEMU } & \text { West African Economic and Monetary Union } \\ & \end{array}$




\section{References}

Assibey-Mensah, George O., 1997, "The Context of Budgeting for Development in Developing Economies: A Conceptual Note" (unpublished; Gary, Indiana: Indiana University, School of Public and Environmental Affairs).

Boughton, James M., and Alex Mourmouras, 2002, "Is Policy Ownership An Operational Concept?" IMF Working Paper 02/72 (Washington: International Monetary Fund).

Bouley, Dominique, Jerome Fournel, and Luc E. Leruth, 2002, "How Do Treasury Systems Operate in Sub-Saharan Francophone Africa?” IMF Working Paper 02/58 (Washington: International Monetary Fund).

Campos, Ed, and Sanjay Pradhan, 1996, "Budgetary Institutions and Expenditure Outcomes," World Bank Policy Research Working Paper 1646 (Washington: World Bank).

Center for Accountability and Performance, 1999, Performance Measurement, Concepts and Techniques (Washington: American Society for Public Administration, $2^{\text {nd }}$ ed.).

Chu, Ke-young, and Richard Hemming, eds., 1991, Public Expenditure Handbook: A Guide to Public Policy Issues in Developing Countries (Washington: International Monetary Fund).

Conan, M., 1997, Finances Publiques (Paris: Nathan).

Dia, Mamadou, 1996, Africa's Management in the 1990s and Beyond: Reconciling Indigenous and Transplanted Institutions (Washington: World Bank).

Diamond, Jack, 2003, "From Program to Performance Budgeting: The Challenge For Emerging Countries,” IMF Working Paper (Washington: International Monetary Fund, forthcoming).

Ecole Nationale du Trésor Public, 2000a, Dépense de l’État (Paris: Trésor Public). ,2000b, Comptabilité de l'État (Paris: Trésor Public).

Euzéby, Alain, and Marie-Luise Herschtel, 1990, Finances Publiques, Une Approche Economique (Paris:Dunod).

Fowler, Floyd J., 1993, Survey Research Methods, Applied Social Research Methods Series, Vol. 1 (Newbury Park, California: Sage, $2^{\text {nd }}$ ed.).

Harriss, John, Janet Hunter, and Colin M. Lewis, eds., 1995, The New Institutional Economics and Third World Development (New York: Routledge).

Kachigan, Sam Kash, 1986, Statistical Analysis: An Interdisciplinary Introduction to Univariate and Multivariate Methods (New York: Radius Press). 
Magnet, Jacques, 1996, Éléments de Comptabilité Publique (Paris: Librairie Générale de Droit et de Jurisprudence, $3^{\text {rd }}$ ed.).

Mikesell, John L., 1995, Fiscal Administration: Analysis and Applications for the Public Sector (Belmont, California: Wadsworth, $4^{\text {th }}$ ed.).

Lienert, Ian, 2003, “A Comparison Between Two Public Expenditure Management Systems in Africa,” IMF Working Paper 03/2 (Washington: International Monetary Fund).

Ministère de l'Économie, des Finances et du Plan, 1995, Le Budget de l'État, de la Préparation à l'Exécution, Les Éditions de Bercy, Études (Paris).

Muzellec, Raymond, 1997, Finances Publiques (Paris:Editions Dalloz, $10^{\text {th }}$ ed.).

Potter, Barry H., and Jack Diamond, 1999, Guidelines for Public Expenditure Management (Washington: International Monetary Fund).

Premchand, A., 1983, Government Budgeting and Expenditure Controls: Theory and Practice (Washington: International Monetary Fund). , ed., 1990, Government Financial Management: Issues and Country Studies (Washington: International Monetary Fund).

Ramakrishnan, Subramaniam, 1998, "Budgeting and Financial management in Sub-Saharan Africa: Key Policy and Institutional Issues," Development Discussion Paper No. 622 (Cambridge, Massachusetts: Harvard Institute for International Development).

Sekwat, Alex, 1997, "Public Budgeting Deficiencies in Sub-Saharan Africa: A Review," Journal of Public Budgeting, Accounting \& Financial Management, Vol. 9 (Spring), pp. 143-61.

United Nations, 1991, Government Financial Management in Least Developed Countries (New York: United Nations).

Weimer, David L., and Aidan R.Vining, 1992, Policy Analysis: Concepts and Practice (Englewood Cliffs, New Jersey: Prentice Hall, $2^{\text {nd }}$ ed.).

Welch, Susan, and John Comer, 1988, Quantitative Methods for Public Administration: Techniques and Applications (Orlando, Florida: Harcourt Brace, $2^{\text {nd }}$ ed.).

Wildavsky, Aaron, and Naomi Caiden, 1997, The New Politics of the Budgetary Process (New York: Longman, $3^{\text {rd }}$ ed.).

Williams, W. Anderson, 2002, "Trusting the Numbers: The Power of Data Verification," Government Finance Review, Vol. 18 (April), pp. 18-21. 
World Bank, 1999, Public Expenditure Management Handbook (Washington: World Bank).

Yonaba, Salif, 2002, "La Difficile Intégration des Règles Budgétaires et Comptables des États Membres de l'Union Économique et Monétaire Ouest-Africaine (UEMOA)," Revue Française de Finances Publiques, Vol. 79 (September), pp. 221-39. 